\title{
Competitive Circular Economy Management. The Mitsubishi Corporation Case
}

\author{
Silvio M. Brondoni*
}

\begin{abstract}
In today's scenario of 'hyper competition', global corporations face many other MNCs (more and more frequently based in the US, China, South Korea, Taiwan and Europe). In oversize economy, global companies move to adopt closed innovation policies. In particular, the circular economy suggests that sustainable outputs can be achieved without loss of revenue or extra costs for global manufacturers.

The transformation from MNCs to global networks has led towards vertical specialization and highly diversified patterns of collaboration through inter-firm and intra-firm transactions coordinated by global corporations. As we can see from the experience of the greatest global corporations (e.g., Mitsubishi Corporation), the biggest global companies see the circular economy as a specific tool to compete, in the context of a network vision (competitive circular economy management).
\end{abstract}

Keywords: Circular Economy; Competitive Circular Economy; Oversize Economy; Mitsubishi Corporation; Mitsubishi Mineral Resources Group; Recycling; Global Markets; Global Competition

\section{Global Markets and New Rules of Competition}

In today's scenario of 'hyper competition', global corporations face many other MNCs (more and more frequently based in the US, China, South Korea, Taiwan and Europe). In this new competitive landscape, capitalism breaks the static, monolithic rules of the company that plans, produces and sells by the rules of absolute proximity (local market) or relative proximity (international market) (Brondoni, 2019a).

The primacy of knowledge management, the worldwide localization of production and the new policies of innovation and imitation have been modified in opportunities for worldwide joint ventures, global competitive alliances and merger and acquisitions (Ali et al., 2017; Brondoni, 2012). Because of concentration, consolidations in several industries have involved a 'mega-merger' of corporate giants that has radically transformed the competitive balance in many sectors (Brondoni, 2014).

The nowadays globalization phase (competitive globalization) is characterized by an increasing number of over-supplied markets, as well as a key-role of dimensional growth. The last one is a fundamental driver for the firm's development, by determining its success or decline (Brondoni, 2008).

* Full Professor of Market-Driven Management, Niccolò Cusano University (silvio.brondoni@unicusano.it)

Brondoni, S. M. (2020). Competitive Circular Economy Management. The Mitsubishi Corporation Case. Symphonya. Emerging Issues in Management (symphonya.unicusano.it), (1), 10-25. 
In oversize economy, global companies move to adopt closed innovation policies, operating in sectors that became protected from competition. With global closed innovation policies, a certain number of mega-organizations concentrate their expertise in governing market power through innovation processes in global structures.

\section{The Circular Economy}

Linear industrial processes create products with a finite lifespan, which end up in incinerators or in landfills. The circular economy, by contrast, takes insights from living systems and it considers a "regenerative" approach (Garcés-Ayerbe et al., 2019). The regenerative approach is in contrast to the traditional linear economy, which has a "take, make, dispose" model of production (Ellen Mac Arthur Foundation, 2012).

The circular economy usually defines an economic system focused on the elimination of waste and the continual use of resources. In this sense, circular economy is a production and consumption model that involves sharing, reusing, repairing and recycling existing products and materials as much as possible, expanding the life cycle of products, minimizing waste and pollution, and creating a close-loop system (Geissdoerfer et al., 2017).

The traditional vision of circular economy rests on three principles (Ellen Mac Arthur Foundation, 2015):

1. preserving and enhancing natural capital by controlling finite stocks and balancing renewable resource flows;

2. optimizing resource yields by circulating products, components and materials in use at the highest utility;

3. fostering system effectiveness by revealing and designing out negative externalities.

The circular economy suggests that sustainable outputs can be achieved without loss of revenue or extra costs for manufacturers, and especially without a drop in the quality of products for consumers (Ellen Mac Arthur Foundation, 2013).

The circular economy does not change the profit-maximization paradigm of businesses. It suggests, by contrast, an alternative model from linear forms of production, targeted to value chains based on the development of new core competencies. Indeed, it creates superior performances that cut costs, improve efficiency, and meet the expectations of consumers and the government regulations (Ellen Mac Arthur Foundation, 2015; Ellen Mac Arthur Foundation 2014).

\section{The Competitive Circular Economy}

The number of circular economy-related publications has increased rapidly since 2007, and a large number of articles were published in the 2014-2016 period. The academic studies focused on circular economy could be classified into three main groups: 
1. a first group is concerned with a definition of circular economy (Korhonen et al., 2018; Prieto-Sandoval et al., 2018; Kirchherr et al., 2017);

2. a second group regards the theoretical background of the circular economy concept. These works are usually focused on an industrial ecology background (Saavedra et al., 2018; Murray et al., 2017; Lieder \& Rashid, 2016);

3 . the third group of papers, finally, encompasses empirical analyses (De-Jesus et al., 2018; Ormazaba et al., 2018; Ranta et al., 2017).

However, in many scientific publications, it is generally accepted that the circular economy is a paradigm shift attempting to integrate economic activity and environmental wellbeing (Prieto-Sandoval, et al., 2018), replace the end-of-life concept with the 4Rs - reducing, reusing, recycling and recovering - in production and consumption processes, and slow down, close and narrow material and power loops (Kirchherr, et al., 2017).

The principal and traditional aims of implementing a circular economy strategy in an organization are to reduce virgin materials and waste output and to protect the environment and prevent pollution (Haas, et al., 2015; Ma, et al., 2014). Thus stretching the economic life of goods and materials, closing loops and minimizing waste, that is, the circular economy replaces production with sufficiency (Stahel, 2016; Gregson et al., 2015).

In other words, a circular economy strategy generates a sustainable development through increased resource efficiency (Haas, et al., 2015).

This definition underpins the assumption that resources are finite and have to be managed to sustain future generations (Garcés-Ayerbe et al., 2019). In fact, sustainable development refers to a 'development that meets the needs of the present without compromising the ability of future generations to meet their own needs' (OECD, 2017).

Empirical studies related to circular economy practices are scarce. One of these works describes four different modes of adopting circular economy principles in firms, considering the value network and customer value proposition and interface: linear, downstream circular, upstream circular, and full circular, depending on the degree of circularity (Urbinati et al., 2017).

$\square$ «The study explores the adoption of Circular Economy under the lens of the business model literature and proposes a new taxonomy that explains different degrees of circularity in practice adopted by firms in different industries. In particular, we focus the distinction of Circular Economy Business Models on the differences emerging on two major dimensions: the (i) customer value proposition \& interface, i.e. the implementation of the circularity concept in proposing value to customers; the (ii) value network, i.e. the ways through which interacting with suppliers and reorganizing the own internal activities. Accordingly, the paper highlights four available modes of adoption of Circular Economy, i.e. Linear, Upstream Circular, Downstream Circular and Full Circular. In particular, it appears that these modes [...] seem to represent just different modes of adoption of Circular Economy principles, which mainly depend on the willingness of the company, 
i.e. the management commitment, to adopt Circular Economy principle» (Urbinati et al., 2017).

Up to now, the macroeconomic view said that when implementing circular economy activities in a business, the company should consider its own dynamic environment, and stakeholders' movements, positions and preferences. However, this approach was very limited in these last years, because it does not point out to the critical role of competitors, and especially of global market competition. By contrast, we have now to consider an approach focused on conditions of oversize economy competition.

Since 2010, globalisation has imposed a new view of the competitive environment in which competitors are not always direct rivals. On the contrary, as a result of alliances and agreements, certain firms can become competitors in the sense that together they contribute to the common objective of generating greater profits, with mega-organisations that have the potential to change the long-term competitive structure of sectors (oversize economy) (Brondoni, 2019a; Brondoni \& Bosetti, 2018).

$\square$ The concept of a "circular" recycling-oriented economy has been gaining ground in recent years, particularly in Europe. Unlike the current situation, whereby natural resources can be freely mined, manufactured, consumed and disposed of on a global scale, a circular economy would involve transforming mechanisms throughout society from a broader perspective. Japan meanwhile has continued to lead the world in activities aimed at reducing environmental impact by reducing, reusing and recycling waste, based on the concept of a recycling-oriented society. While all this has been going on, Mitsubishi Materials has built up experience, expertise and advanced technologies through its diverse recycling operations (Shimotaya, 2015).

\section{The Mitsubishi Group and the Global Management of Competitive Circular Economy}

Mitsubishi Corporation is a global integrated business enterprise that develops and operates businesses together with its offices and subsidiaries in approximately 90 countries and regions worldwide, as well as a global network of around 1,500 group companies (Mitsubishi Corporation, 2020; Mitsubishi Corporation, 2019).

Mitsubishi Corporation has 10 Business Groups that operate across virtually every industry: Natural Gas, Industrial Materials, Petroleum \& Chemicals, Mineral Resources, Industrial Infrastructure, Automotive \& Mobility, Food Industry, Consumer Industry, Power Solution and Urban Development. Through these 10 Business Groups, Mitsubishi Corporation's current activities have expanded far beyond its traditional trading operations to include project development, production and manufacturing operations, working in collaboration with our trusted partners around the globe. 
The Three Corporate Principles were formulated in 1934, as the action guidelines of Mitsubishi Trading Company (Mitsubishi Shoji Kaisha), based on the teachings of Koyata Iwasaki, the fourth president of Mitsubishi.

Although Mitsubishi Trading Company ceased to exist as of 1947, the principles were adopted as Mitsubishi Corporation's corporate philosophy, and this spirit lives on in the actions of today's management and employees. The Three Corporate Principles also serve as the cornerstone of the management ethos of the so-called Mitsubishi group of companies. Active in many businesses fields and united by a common history and philosophy, the Mitsubishi companies continue to grow through a strong spirit of friendly competition with one another (Mitsubishi Corporation, 2020; Mitsubishi Corporation 2019).

$\square$ Recent developments have dramatically changed the playing field, and Mitsubishi Corporation Group must now take stock of factors such as heightened geopolitical risk and an increasingly borderless global society and market.

In response to these complex and rapid changes, and in order to accelerate the implementation of Mitsubishi Corporation's business management model, the Regional CEO operating structure across seven key overseas regions was abolished since last fiscal year. The new structure is designed to promote regional strategies that optimize direct collaboration throughout the global network including approximately 1,500 group companies in 90 countries and regions around the world. Mitsubishi Corporation will leverage its global network under this reorganized structure to gather and communicate relevant, real-time business intelligence.

Corporate Management Support Offices have been established in New York, London, and Singapore to shore up the growth and independence of Mitsubishi operating companies.

In this manner, the Mitsubishi Corporation Group aims to maximize its business value by enhancing its global network and taking full advantage of the Mitsubishi Corporation Group's collective global abilities, including its good relationships with customers and partners around the world. The Mitsubishi Corporation Group includes approximately 1,500 enterprises. The Mitsubishi Corporation Group works to raise their consolidated earnings; it remains equally committed to growing their individual corporate value. By leveraging the diverse expertise found throughout its network of group companies and more than 130 Business Units, Mitsubishi Corporation shall continue to innovate and inspire global industries. Mitsubishi Corporation's Human Resources system is focused on: (1) Ensure that employees gain the right experience to become management professionals earlier in their careers; (2) Be more meritocratic to ensure that the right people are assigned to the right positions; and (3) Utilize management talent more widely and effectively throughout the Mitsubishi Corporation Group. 
To enhance the Mitsubishi Corporation Group business creation capabilities, since April 2019 the corporation's activities have been restructured into 10 - Business Groups (Table 1) as:

- Natural Gas Group;

- Industrial Materials Group;

- Petroleum \& Chemicals Group;

- Industrial Infrastructure Group;

- Automotive \& Mobility Group;

- Food Industry Group;

- Consumer Industry Group;

- Power Solution Group;

- Urban Development Group, and finally;

- Mineral Resources Group.

Table 1: Mitsubishi 10-Business Groups

\section{Natural Gas Group}

Mitsubishi Corporation has been involved in the production, transport, trade, and import agent business of LNG since 1969. The Natural Gas Group engages in the business of liquefied natural gas (LNG), the demand of which is expected to grow due to various factors including the transition to low-carbon societies.

\section{Industrial Materials Group}

The Industrial Materials Group engages in product sales, business development and investments in the automotive \& mobility, construction and infrastructure sectors, where Mitsubishi Corporation handles a wide variety of materials such as carbon, steel products, and many other performance materials. Against a backdrop of an increasingly competitive environment, the mission is to redefine the role Mitsubishi Corporation can play in providing solutions to the industries in which it operates and focus resources in areas where the company can leverage its strengths and capabilities.

\section{Petroleum \& Chemicals Group}

The transition to low-carbon societies and arising of environmental awareness continue to have an impact on the petroleum and chemicals industry. The mission is to find solutions in these industries by concentrating on its core businesses. The Petroleum \& Chemicals Group's mission is to secure stable supplies of energy and chemical materials, products that are essential to industries, societies and everyone's quality of life.

\section{Industrial Infrastructure Group}

The mission is to redefine Mitsubishi Corporation's position in the industry by transitioning to high value-added business models. The Industrial Infrastructure Group is connected with a broad range of industries and partners, to develop (in various industries, such as technological innovations, digitization, and transformation of industrial structures) a variety of business models in the fields of plant engineering, industrial machinery, as well as maritime and aerospace-related business. 


\section{Automotive \& Mobility Group}

The mission is to capture demand and leverage Mitsubishi Corporation's business foundations in the evolving automotive and mobility industries, which are embracing digital technologies and services encapsulated by CASE (Connected, Autonomous, Sharing and Electric). In the Automotive \& Mobility Group, Mitsubishi Corporation has developed its business in the production, sales \& distribution, financing and after-sales service of passenger and commercial vehicles, and focusing on the so-called "Automotive Value Chain" on a global scale with a focus on ASEAN (Association of South-East Asian Nations) countries.

\section{Food Industry Group}

The Food Industry Group is engaged in businesses that deliver food-related products to consumers all over the world. The operations cover food resources, fresh foods, consumer products, food ingredients and other products. Mitsubishi Corporation is active in every link of the supply chain, from the production and sourcing of raw materials to the manufacturing of finished food products. The Group contributes to Japanese companies by expanding their quality products and services into overseas markets.

\section{Consumer Industry Group}

The Consumer Industry Group is focused on major challenges faced by consumers in the retail, apparel, SPA (specialty store retailer of private label apparel), healthcare, food distribution and logistics, tire industries, consumer marketing, and paper and packaging. The mission is to maximize the value of Mitsubishi Corporation's real-assets as social infrastructure, such as its retail stores network. It also effectively combines its real assets and digital technologies to build consumeroriented retail-and-distribution platform businesses.

\section{Power Solution Group}

The Power Solution Group consists of two divisions, the International Power Division and the Energy Services Solution Division. Mitsubishi Corporation is conducting various initiatives in response to diversifying electricity needs. Main initiatives are the renewable energy business, the creation of new businesses in the electric power field that utilize distributed solar power generation, etc., and the lithium-ion battery business, which is indispensable for the spread of electric vehicles. The mission is to contribute to stable power supplies, and to create new benefits for power consumers/users by combining renewables and other environmentally friendly energy sources.

\section{Urban Development Group}

The Urban Development Group promotes the businesses of the three following divisions. The Urban Infrastructure Division focuses on the development and management of airports, railways, roads, water supplies, and data centres. The Urban Development Division focuses mainly on urban development projects in ASEAN, and is engaged in the development of industrial facilities, retail facilities, and housing properties, primarily in Japan, North America and Asia. It also creates and manages real estate funds. The Asset Finance Division offers a wide variety of financial services including leasing, installment sales and asset finance through Mitsubishi UFJ Lease \& Finance Co., Ltd. and provides aircraft and automobile leasing services.

\section{Mineral Resources Group}

The Mineral Resources Group is engaged in the trading, business development, and investment of various mineral resources and metals. These include ferrous raw materials such as metallurgical coal and iron ore, as well as non-ferrous metals such as copper, precious metals and aluminium. It also provides high value added global trading services, such as logistics, financing, and sophisticated risk management. By operating businesses that adapt to the global market, the Mineral Resources Group's mission is to further enhance the competitive advantage as well as the quality of its world-class quality assets, while delivering long-term sustainability in ways, which are good for the environment and for the supply chain (Mitsubishi Corporation, 2020). 


\section{Mitsubishi Mineral Resources Group and the Management of Competitive Circular Economy}

With its history tracing back to a coal mining and mining business as the roots of the Mitsubishi Group, Mitsubishi Mineral Resources has supported the modernization of Japan. While recent years have seen a rapid increase in the demand for many mineral resources due to the industrial development of emerging countries, restrictions related to resources have been increasing. For example, many resourceproducing countries restrict exports under protectionism, while major resources companies progress and expand their power.

In Japan, which relies on imports for many mineral resources, it is a major challenge to secure resources and ensure the stable supply of materials and products demanded in society while firmly maintaining appropriate prices and fair trade (Ono, 2015).

Having gone through changing times, Mitsubishi Mineral Resources is now a comprehensive material manufacturer that supplies basic materials (Figure 1).

Figure 1: Mitsubishi Mineral Resources Group. Corporate Philosophy \& LongTerm Management Strategy

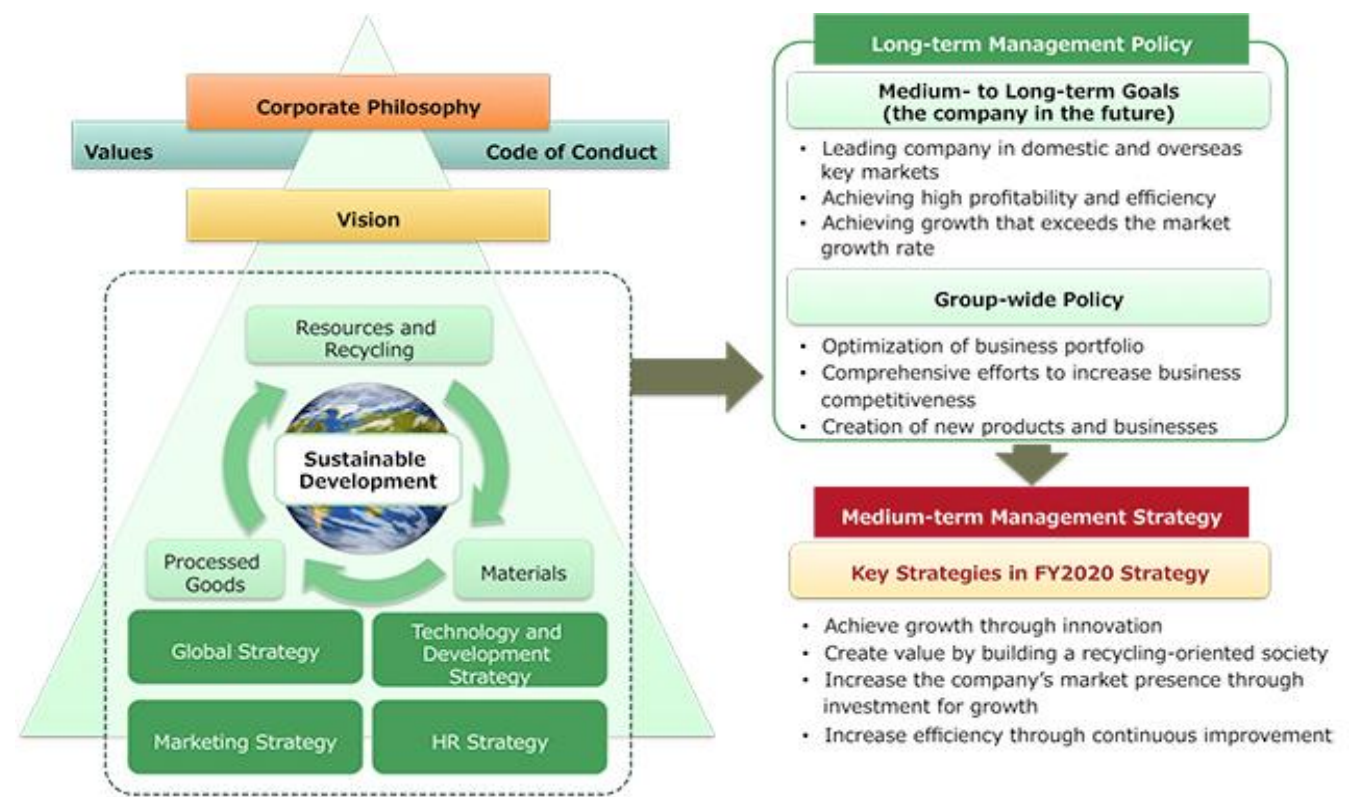

Source: Mitsubishi Corporation, Investor Relations (2017). Medium-Term Management Plan, May.

In recent years, e-scrap has attracted increasing attention as a new and valuable source of raw materials for smelting. Furthermore, amid growing environmental concerns, the amount of e-scrap recovered is expected to increase in line with the higher recycling rates of home appliances and other items.

With so many different challenges becoming apparent in the resource sector, there has been a renewed focus on the importance of resource recycling. In the EU for 
instance there has been much discussion regarding the concept of a "circular economy."

Discarded circuit boards from home appliances, personal computers, smart phones and other mobile phones, network equipment and various other electronics are commonly referred to as e-scrap and composed of a high concentration of gold, silver, copper, palladium and other valuable metals. This is the source for a new supply of valuable smelting materials, which in recent years has been gaining attention as an urban mine. Taking advantage of the Mitsubishi process for continuous copper smelting, a unique technology for smelting precious metals with the lowest environmental impact in the industry, Mitsubishi Mineral Resources promoted the expansion of e-scrap receiving and processing, through the combined operations of its Naoshima facility and Group Company Onahama Smelting and Refining Co., Ltd. (Ono, 2015).

\title{
$\square$ The Mitsubishi Mineral Resources Vision reads as follows: «We will become the leading business group committed to creating a sustainable world through materials innovation, with use of our unique and distinctive technologies, for People, Society and the Earth».
}

One of the key characteristics of Mitsubishi Mineral Resources Group is the "urban mine" recycling business, which enables the company to extract (recycle) resources more efficiently than developing natural underground resources, with less of an impact on the environment or local communities.

With e-scrap recycling operations, Mitsubishi Mineral Resources efficiently recycles on global scale high-value resources such as gold and silver as part of the metal smelting processes used for core operations, whilst at the same time effectively separating and treating harmful substances.

On other fronts, Mitsubishi Mineral Resources is working to recycle a wide range of resources that are inextricably linked, including aluminium cans, used home appliances, electronic devices and vehicles, which contain more and more electrical components these days. Mitsubishi Mineral Resources applied the copper smelting process to establish a recycling system, for recovering valuable metals from metal and electronic waste (e-scrap) (Table 2).

Table 2: Mitsubishi Mineral Resources Group. The Recycling System

\author{
Plea Cement Plants \\ A-1 Aomori Plant \\ A-2 Iwate Plant \\ A-3 Yokoze Plant \\ A-4 Kyushu Plant (Kanda District) \\ A-5 Kyushu Plant (Kurosaki District)
}




\section{Smelters}

B-1 Naoshima Smelter \& Refinery

B-2 Ikuno Plant

B-3 Hosokura Metal Mining Co., Ltd. (Hosokura Smelter)

B-4 Onahama Smelting \& Refining Co., Ltd. (Onahama Smelter)

\section{Metal Recycling Plants}

C-1 Materials Eco-Refining Co., Ltd. Onahama Plant

C-2 Materials Eco-Refining Co., Ltd. Akita Plant

\section{Metal Processing Plants}

D-1 Tsukuba Plant

\section{Tungsten Recycling Plants}

E-1 Japan New Metals Co., Ltd. Akita Plant

\section{Functional Materials Plants}

F-1 Sanda Plant

F-2 Shizuoka DBA Center

\section{Silicon-Related Plants}

G-1 Yokkaichi Plant

Chemical-Related Plants

H-1 Mitsubishi Materials Electronic Chemicals Co., Ltd. Head Office

Aluminum Can Manufacturing Plants

I-1 Universal Can Corp. Okayama Plant

I-2 Universal Can Corp. Gunma Plant

\section{Comprehensive Aluminum Can Rolling Plants}

J-1 Mitsubishi Aluminum Co., Ltd. Fuji Plant

\section{Home Appliance Recycling Plants}

K-1 Chubu Eco Technology Co., Ltd.

K-2 East Japan Recycling Systems Corp.

K-3 Hokkaido Eco Recycle Systems Co., Ltd.

K-4 Panasonic Eco Technology Kanto Co., Ltd.

K-5 Kansai Recycling Systems Co., Ltd.

\section{Incineration Fly Ash Recycling Plant}

L-1 Kitakyushu Ash Recycle Systems Co., Ltd.

\section{ELV (End of Life Vehicle) Recycling Plant}

M-1 MARC Corporation

Source: Mitsubishi Corporation (2020). Mineral Resources Group.

In the precious metals department, Mitsubishi Mineral Resources is offering an accumulation plan called "My Gold Partner" for gold, silver and platinum, providing an alternative for private investors' asset building (Ono, 2015).

$\square$ «Japan's Mitsubishi Mineral Resources is planning to invest over $\$ 100$ million to boost its global e-scrap processing footprint. The investment will see the firm spend up to \$107 million in several new facilities in Japan and one in the Netherlands, according to a 
report from Nikkei Asian Review. The company is part of the Mitsubishi Group. The new plants are not expected to open until 2021, but will reportedly boost the company's annual processing capacity of precious metals by 40 percent. Hisashi Tateyashiki, the general manager of Mitsubishi Materials' e-scrap business, discussed the company's growing operations at last month's escrap 2017. Tateyashiki said "in all parts of the world e-scrap generation will increase" and that the company was primed to take advantage of the opportunity.

Tateyashiki said the company currently operates two e-scrap facilities in Japan. A facility in Naoshima has an annual processing capacity of 110,000 metric tons per year and a smaller site in Onahama can process about 30,000 metric tons per year. Those facilities currently recover gold, silver, platinum and palladium. They also recover copper, a base metal.

Bloomberg View recently explored the growth of Japan's recycling industry, including Mitsubishi's massive investment, in connection to China's increasingly stringent policies on importing recyclables from other countries» (Elliot, 2017).

As a diversified materials manufacturer, the Mitsubishi Mineral Resources Group has strived to work "For People, Society and the Earth" through the supply of basic materials.

Mitsubishi Mineral Resources enhanced the research and development of unique and distinctive technologies and products in order to respond to the increasingly diversified global needs that require superior products, systems and services. Today, the scope of operations is extensive, ranging from the manufacture of resources and basic materials to high-performance processed products and new materials, as well as the provision of systems, engineering services and resource recycling, with a circular economy approach of resources and raw materials (Figure 2).

Through operations, Mitsubishi Mineral Resources promotes materials innovation that addresses the emerging global challenges of technical innovation, information technology advancement, globalisation and enhanced environmental awareness.

Globalisation has radically modified the traditional fundamental principles of industrial output constituted by the static localisation of manufacturing facilities, the presence of workers at manufacturing sites, and stocks of raw, semi-finished materials. 
Figure 2: Mitsubishi Materials Group. The Resource Recycling Network

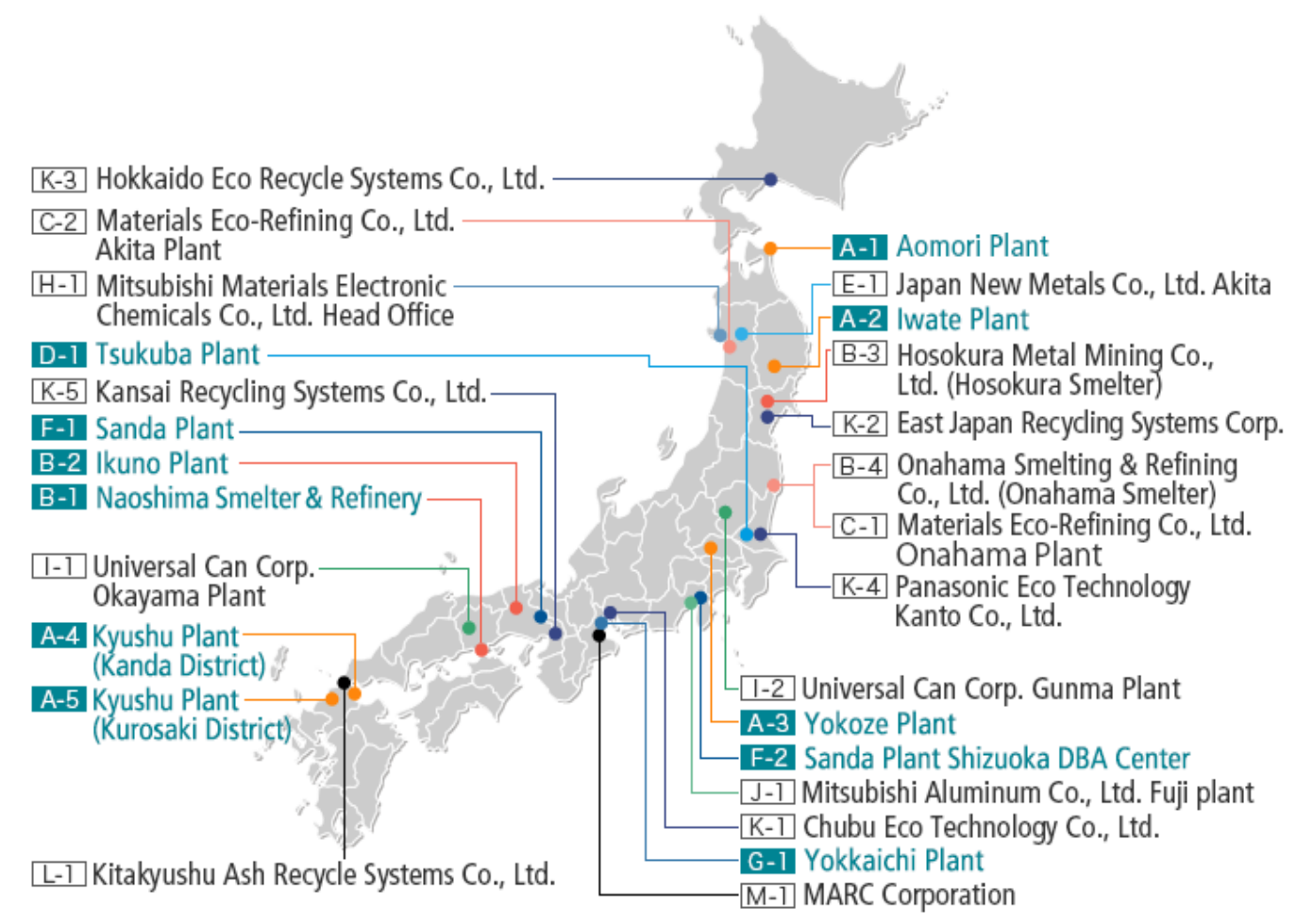

Source: Mitsubishi Corporation. Mineral Resources Group (2020).

Conversely, in Europe the circular economy is still focused on a potential way for our society to increase prosperity, while reducing dependence on primary materials and energy.

$\square$ «The circular economy should be a central political project for Europe, as it offers the potential to set a strong perspective on renewed competitiveness, positive economic development, and job creation. Growth within: a circular economy vision for a competitive Europe makes a strong case for business models centred on use, rather than consumption, and regenerative practices that have, on top of economic advantages, beneficial impacts for society as a whole.» (Ida Auken, Member of Parliament, Denmark, 2015)

$\square$ «By combining efficiency and effectiveness - doing the right things - the European economy would experience win-win-win. Lower costs, less carbon emissions, and more employment. Very good news in a situation where environment and resource concerns too often have been seen mainly as a cost and threat to competitiveness.» (Anders Wijkman, Co-President, Club of Rome, 2015) 
With this romantic vision, the European Commission is expected to propose "circular economy packages", and so doing many business leaders could embrace the circular economy as a path to increasing growth and profitability. At the same time, a lively debate is going on about the attractiveness of a circular economy for different stakeholders and its implications for employment, growth, and the environment (Ellen MacArthur Foundation et al., 2015).

\section{Emerging Issues}

The transformation from MNCs to global networks has led towards vertical specialization and highly diversified patterns of collaboration through inter-firm and intra-firm transactions coordinated by global corporations (Brondoni, 2019b). Global networks have significantly reduced the importance of 'context specific skills' (Hayashi, 2002). The traditional rules of oligopolies have completely changed, with links between firms becoming strategic on a very large scale, and industrial rivalry tending to occur among global networks comprising a multiplicity of firms with different knowledge bases, particularly focused on managing innovation and creative imitation (Wood et al., 2019; Brondoni, 2013).

As we can see from the experience of the greatest global corporations (e.g., Mitsubishi Corporation), the world's reality is quite different and now the biggest global companies see the circular economy simply as a specific tool to compete, in the context of a network vision (McIntyre \& Ortiz, 2016).

In fact, in big global corporations, the circular economy is often widely applied within a company's network. From this perspective, the corporate task of some companies is specifically oriented towards recycling, while other companies belonging to the same group use raw materials obtained from recycling, thus gaining an extensive competitive advantage for all the companies belonging to the same network (competitive circular economy).

\section{Bibliography}

Ali, M., Babai, M.Z., Boylan, J. E., \& Syntetos A.A. (2017). Supply Chain Forecasting when Information Is Not Shared, European Journal of Operational Research, 260, 3, August, 984-994. http://dx.doi.org/10.1016/j.ejor.2016.11.046

Boiral, O., \& Heras-Saizarbitoria, I. (2017). Managing Biodiversity Through Stakeholder Involvement: Why, Who, and for What Initiatives? Journal of Business Ethics, 140(3), 403-421. http://dx.doi.org/10.1007/s10551-015-2668-3

Brondoni, S. M. (2019b). 4.0 IR, Oversize Economy and the Extinction of Mammoth Companies. Symphonya. Emerging Issues in Management (symphonya.unicusano.it), (2), 8-24.

http://dx.doi.org/10.4468/2019.2.02brondoni

Brondoni, S.M. (2019a). Shareowners, Stakeholders \& the Global Oversize Economy. The Coca-Cola Company Case. Symphonya. Emerging Issues in Management (symphonya.unicusano.it), (1), 16-27. http://dx.doi.org/10.4468/2019.1.02brondoni 
Brondoni, S. M., \& Bosetti, L. (2018). Ouverture de 'Integrated CSR Management'. Symphonya. Emerging Issues in Management (symphonya.unimib.it), (1), 1-17.

http://dx.doi.org/10.4468/2018.1.01ouverture

Brondoni, S. M. (2014). Global Capitalism and Sustainable Growth. From Global Products to Network Globalisation, Symphonya. Emerging Issues in Management (symphonya.unimib.it), (1), 10-31.

http://dx.doi.org/10.4468/2014.1.02brondoni

Brondoni, S. M. (2013). Innovation and Imitation for Global Competitive Strategies. The Corporation Development Models of US, Japan, Korea, and Taiwan. Symphonya. Emerging Issues in Management (symphonya.unimib.it), (1), 12-27.

http://dx.doi.org/10.4468/2013.1.02brondoni

Brondoni, S. M. (2012). Innovation and Imitation: Corporate Strategies for Global Competition. Symphonya. Emerging Issues in Management (symphonya.unimib.it), (1), 10-24.

http://dx.doi.org/10.4468/2012.1.02brondoni

De-Jesus, A., \& Mendoça, S. (2018). Lost in Transition? Drivers and Barriers in the Eco-Innovation Road to the Circular Economy. Ecological Economics, 145(C), 75-89.

http://dx.doi.org/10.1016/j.ecolecon.2017.08.001

Ellen Mac Arthur Foundation, \& McKinsey Center for Business and Environment (2015). Growth Within: A Circular Economy Vision for a Competitive Europe, June.

Ellen Mac Arthur Foundation (2015). Towards the Circular Economy. Economic and Business Rationale for an Accelerated Transition, Ellen Mac Arthur Foundation, Cowes.

Ellen Mac Arthur Foundation (2015). Circularity Indicators: an Approach to Measuring Circularity.

Ellen Mac Arthur Foundation (2014). Toward the Circular Economy Vol. 3: Accelerating the Scaleup across Global Supply Chains.

Ellen Mac Arthur Foundation (2013). Towards the Circular Economy Vol. 2: Opportunities for the Consumer Goods Sector.

Ellen Mac Arthur Foundation (2012). Towards the Circular Economy: An Economic and Business Rationale for an Accelerated Transition.

Elliot, B. (2017). Mitsubishi Materials Goes All in on Precious Metals Recovery. Nikkei Asian Review, October, 12.

Garcés-Ayerbe, C., Rivera-Torres, P., Suárez-Perales, I., Leyva-de la Hiz, D.I. (2019). Is It Possible to Change from a Linear to a Circular Economy? An Overview of Opportunities and Barriers for European Small and Medium-Sized Enterprise Companies. International Journal of Environmental Research and Public Health, 16(5), 851, 1-15.

http://dx.doi.org/10.3390/ijerph16050851

Geissdoerfer, M., Savaget, P., Bocken, N. M. P., \& Hultink, E. J., (2017). The Circular Economy - A New Sustainability Paradigm? Journal of Cleaner Production, 143, 757-768.

http://dx.doi.org/10.1016/j.jclepro.2016.12.048

Gregson, N., Crang, M., Fuller, S., \& Holmes, H. (2015). Interrogating the Circular Economy: The Moral Economy of Resource Recovery in the EU. Journal Economy and Society, 44, 2, 218-243.

http://dx.doi.org/10.1080/03085147.2015.1013353

Haas, W., Krausmann, F., Wiedenhofer, D., \& Heinz, M. (2015). How Circular Is the Global Economy? An Assessment of Material Flows, Waste Production, and Recycling in the European Union and the World in 2005. Journal of Industrial Ecology, 19(5), 765-777.

http://dx.doi.org//10.1111/jiec.12244

Hayashi, T. (2002). Production Networks of Japanese and American Automobile Industry: Contrasting Evolution and Convergence. East West Center Working Papers, Economics Series, n. 45, May, Honolulu.

Kirchherr, J., Reike, D., \& Hekkert, M. (2017) Conceptualizing the Circular Economy. An Analysis of 114 Definitions. Resources, Conservation and Recycling, 127, 221-232. 
http://dx.doi.org/10.1016/j.resconrec.2017.09.005

Korhonen, J., Honkasalo, A., \& Seppälä (2018). J. Circular Economy: The Concept and its Limitation. Ecological Economics, 143, 37-46.

http://dx.doi.org/10.1016/j.ecolecon.2017.06.041

Korhonen, J., Nuur, C., Feldmann, A., \& Birkie, S.E. (2018). Circular Economy as an Essentially Contested Concept. Journal of Cleaner Production, 175, 20, 544-552.

http://dx.doi.org/10.1016/j.jclepro.2017.12

Lieder, M., \& Rashid, A. (2016). Towards Circular Economy Implementation: A Comprehensive Review in Context of Manufacturing Industry. Journal of Cleaner Production, 115, 36-51.

http://dx.doi.org/10.1016/j.jclepro.2015.12.042

Ma, S.-H, Wen, Z.-G., Chen, J.-N., \& Wen, Z.-C. (2014). Mode of Circular Economy in China's Iron and Steel Industry: A Case Study in Wu'an city. Journal of Cleaner Production, 64, 505-512.

http://dx.doi.org/10.1016/j.jclepro.2013.10.008

McIntyre K., Ortiz J.A. (2016). Multinational Corporations and the Circular Economy: How Hewlett Packard Scales Innovation and Technology in Its Global Supply Chain, in Clift, R., \& Druckman, A. (eds.), Taking Stock of Industrial Ecology, Springer, Heidelberg.

http://dx.doi.org/10.1007/978-3-319-20571-7_17

Mitsubishi Corporation (2020). Corporate Brochure.

https://www.mitsubishicorp.com/jp/en/

Mitsubishi Corporation (2019). Integrated Report. Invisible Connections.

https://www.mitsubishicorp.com/jp/en/ir/library/ar/pdf/areport/2019/all.pdf

Murray, A., Skene, K., \& Haynes, K. (2017). The Circular Economy: An Interdisciplinary Exploration of the Concept and Application in a Global Context. Journal of Business Ethics, 140(3), 369-380. http://dx.doi.org/10.1007/s10551-015-2693-2

OECD (Organisation for Economic Co-operation and Development) (2017). Enhancing the Contributions of SMEs in a Global and Digitalised Economy, OECD, Paris.

Ono, N. (2015). We Will Enhance our Group Governance Structure and Move forward to Create New Values. Mitsubishi Materials Corporation, June.

https://www.mmc.co.jp/corporate/en/company/topmessage/

Ormazabal, M., Prieto-Sandoval, V., Puga-Leal, R., \& Jaca, C. (2018). Circular Economy in Spanish SMEs: Challenges and Opportunities. Journal of Cleaner Production, 185, 157-167.

http://dx.doi.org/10.1016/j.jclepro.2018.03.031

Prieto-Sandoval, V., Jaca, C., \& Ormazabal, M. (2018). Towards a Consensus on the Circular Economy. Journal of Cleaner Production, 179, 605-615.

http://dx.doi.org/10.1016/j.jclepro.2017.12.224

Ranta, V., Aarikka-Stenroos, L., Ritala, P., \& Mäkinen, S.J. (2017). Exploring Institutional Drivers and Barriers of the Circular Economy: A Cross-Regional Comparison of China, the US, and Europe. Resources, Conservation and Recycling, 135, 70-82.

http://dx.doi.org/10.1016/j.resconrec.2017.08.017

Saavedra, Y. M. B., Iritani, D. R., Pavan, A. L. R., \& Ometto, A. R. (2018). Theoretical Contribution of Industrial Ecology to Circular Economy. Journal of Cleaner Production, 170, 1514-1522.

http://dx.doi.org/10.1016/j.jclepro.2017.09.260

Salvioni, D. M., Astori, R., \& Cassano R. (2014). Corporate Sustainability and Ethical Codes Effectiveness. Journal of Modern Accounting and Auditing, 10(9), 969-982.

Salvioni, D. M., \& Bosetti, L. (2014). Stakeholder Engagement and Integrating Reporting: Evidence from the Adoption of the IIRC Framework. Journal of Strategic and International Studies, 9(3), 78-89.

Salvioni, D. M., \& Gennari, F. (2017). CSR, Sustainable Value Creation and Shareholder Relations. Symphonya. Emerging Issues in Management (symphonya.unimib.it), (1), 36-49. 
http://dx.doi.org/10.4468/2017.1.04salvioni.gennari

Salvioni, D. M., \& Gennari, F. (2019). Stakeholder Perspective of Corporate Governance and CSR Committees. Symphonya. Emerging Issues in Management (symphonya.unicusano.it), (1), 28-39. http://dx.doi.org/10.4468/2019.1.03salvioni.gennari

Shimotaya T. (2015). From Maintaining Stable Supplies of Materials and Products to Recycling. Mitsubishi Materials Corporation, Corporate Report, June.

https://www.mmc.co.jp/corporate/en/csr/sustainable/society.html

Stahel, W. R. (2016). Circular Economy. Nature, March 23, 6-9.

Takeshi Shimotaya T. (2015). From Maintaining Stable Supplies of Materials and Products to Recycling. Mitsubishi Materials Corporation, Corporate Report, June.

https://www.mmc.co.jp/corporate/en/csr/sustainable/society.html

Urbinati, A., Chiaroni, D., \& Chiesa, V. (2017). Towards a New Taxonomy of Circular Economy Business Models. Journal of Cleaner Production, 168, 487-498.

http://dx.doi.org/10.1016/j.jclepro.2017.09.047

Woods J., Brendan Galbraith, B. \& Hewitt-Dundas, N. (2019). Network Centrality and Open Innovation: A Social Network Analysis of an SME Manufacturing Cluster, IEEE Transactions on Engineering Management, 1-14.

http://dx.doi.org/10.1109/TEM.2019.2934765 